\title{
A MAGASAN KVALIFIKÁLT FIATAL MUNKAVÁLLALÓI CSOPORTOK ELEMZÉSÉNEK ÚJ MEGKÖZELÍTÉSI LEHETŐSÉGE: A PREKARIÁTUS
}

\author{
Szerzők: \\ R. Fedor Anita \\ Debreceni Egyetem \\ Egészségügyi Kar \\ Fónai Mihály \\ Debreceni Egyetem \\ Állam- és Jogtudományi Kar \\ Első szerző e-mail címe: \\ fedor.anita@foh.unideb.hu
}

\author{
Lektorok: \\ Bódi Ferenc \\ MTA Társadalomtudományi Kutatóközpont \\ Fábián Gergely \\ Debreceni Egyetem \\ Egészségügyi Kar \\ Bocsi Veronika \\ Debreceni Egyetem \\ Mező Katalin \\ Debreceni Egyetem
}

R. Fedor, Anita \& Fónai, Mihály (2017): A magasan kvalifikált fiatal munkavállalói csoportok elemzésének új megközelítési lehetősége: a prekariátus. Különleges Bánásmód, III. évf. 2017/4. szám, 7-17. DOI 10.18458/KB.2017.4.7

\begin{abstract}
Absztrakt
Írásunkban a friss-diplomások munkaerő-piaci jellemzőit mutatjuk be, egy új, eddig még kevesek által használt elméleti megközelítés, a prekariátus szemüvegén keresztül. Célunk annak feltérképezése, hogy az általunk vizsgált általában kedvezőbb munkaerő-piaci helyzetben lévő társadalmi csoportban mennyire jellemzőek a prekariátus jelenség egyes ismérvei. Tanulmányunkban a prekariátus fogalmát, mint egyfajta munkaerő-piaci bizonytalanságot definiáljuk, melyben olyan kedvezőtlen munkafeltételek koncentrálódnak, mint bizonytalan, rövid távú munkák, határozott idejü munkaszerződés, alacsony bér stb. Ezen jellemzők az anyagi biztonság hiányán túl egy általános létbizonytalansághoz, esetlegesen munkaerő-piaci és társadalmi kirekesztődéshez vezethetnek (LaVaque-Manty 2012, Standing 2012).

Elemző munkánkban arra keressük a választ, hogy a diplomás fiatalok körében mennyire érhető tetten a prekariátus, mint bizonytalan munkaerő-piaci helyzet, s hogy e jelenség mely fó magyarázó változók mentén értelmezhető a leginkább. Kérdésként vetődik fel, a szociodemográfiai, a szociokulturális jellemzők, ezen belül a nem, a családi állapot a megszerzett iskolai végzettség szintje (alap- vagy mesterdiploma, Phd. fokozat), a szakképzettség jellege, a település típusa határozza-e meg leginkább a munkaerö-piaci érvényesülés mikéntjét?

Előzetes eredményeink a nők már korábban is tapasztalt munkaerő-piaci hátrányát erősítik meg. Körükben - a férfiakhoz viszonyítva - például magasabb a határozott munkaszerződéssel foglalkoztatottak aránya, s a munkaerőpiaci-karrier megszakítása is inkább a nőkre jellemző. A "Most nem dolgozom, de már volt munkahelyem" kérdésre igennel válaszolók magasabb
\end{abstract}


arányban kerültek ki a nők köréből. Mindez azt jelzi előre, hogy a kevésbé stabil, kevésbé biztonságos munkaerő-piaci jellemzők inkább a nőket érintik.

Kulcsszavak: fiatalok, kirekesztődés, munkaerőpiac, prekariátus

Diszciplina: szociológia

\begin{abstract}
The study focuses on the labour-market situation of young graduates utilizing the database of the Hungarian Graduate Tracking System. The purpose of the research is to map certain characteristics of the precarious situation posed by the labor market on this group which is in a rather favorable labor market position in comparison to other groups. The concept of precariate is defined as a type of labor-market uncertainty, in which unfavorable working conditions, like insecure short-term jobs, fixed-term employment contracts, low wages, etc.are concentrated.

In addition to the lack of financial security, these characteristics may lead to general insecurity and in some cases to labor market and social exclusion (LaVaque-Manty 2012, Standing 2012). This analysis focuses on the presence of a precarious condition which creates an insecure labour-market situation among young graduates and it attempts to find the main explanatory variables in the interpretation of this phenomenon.

In addition it investigates whether socio-demographic, socio-cultural characteristics, like gender, marital status, type of qualification (BSc, MSc or Ph.D degree), and the type of settlement (village, town, city etc.) affect success in the labour-market. Preliminary results support previous studies that found women in the labor market were disadvantaged. For example, the proportion of women with a fixed employment contract is higher than men, and the interruption of a labor market career is more characteristic of women. More women gave a positive answer to "I am not working at the moment although I have previously had a work place". This suggests that women are more affected by a less stable and less secure labor market than men.
\end{abstract}

Keywords: young people, exclusion, labour-market, precariate

Disciplines: sociology

\title{
Bevezetés
}

A munkaerö-piaci érvényesülést - valamint annak hiányát - számos tényező befolyásolja. Ilyen lehet például a megszerzett iskolai végzettség, a szak vagy szakma típusa, annak szektorális jellege, a munkaerö-piacon megszerzett tapasztalat. Emellett számos egyéni jellemző is alakítja a munka világában való helytállás sikerességét. Ilyen például az alkalmazkodó képesség, tanulékonyság, a szervezeti hierarchia elfogadása. Mindemellett azt is meg kell említeni, hogy bizonyos családi életciklusokban jellemzőbb az instabil munkaerőpiaci helyzet. Ilyen például a gyermekvállalásból adódó lazább munkaerő-piaci kötődés. Ebben az értelemben a hátrányos munkaerő-piaci státuszú csoportokhoz soroljuk a gyermekeket nevelő nőket, a pályakezdőket, az alacsony iskolai végzettségüeket, a községi lakóhellyel rendelkezőket. Ezen csoportok munkavállalási mintázatát számos hazai és külföldi kutatás vizsgálta. Azonban kérdésként vetődik fel, hogy az alapvetően kedvező munkaerőpiaci kondícióval rendelkező frissdiplomások csoportjában fellelhetőek-e karakteres 
munkaerő-piaci hátrányok, $\mathrm{s}$ amennyiben igen milyen föbb dimenziók mentén értelmezhetők a különbségek. Korábbi vizsgálataink elméleti hátterét az inklúzióhoz, integrációszegregációhoz kapcsolódó elméleti keretek adták. Jelenlegi vizsgálatunkban azonban egy új elméleti megközelítéshez nyúlunk, a prekariátus jelenségéhez.

Tanulmányunkban elsőként bemutatjuk a prekariátus definiálásának, és operacionalizálásának lehetőségeit, majd a magyarországi Diplomás Pályakövető Rendszer adatbázisára (2015) támaszkodva bemutatjuk a fiatal diplomások munkaerő-piaci helyzet, úgy hogy kiemelve kezeljük az ún. prekár jellemzőket.

\section{A vizsgálat elméleti hátterét adó új megközelités: a prekariátus}

A prekariátus, mint fogalom a '70-es évek végén jelent meg - elsősorban - a francia szakirodalomban. A fogalmat sokáig a kirekesztés definíciójához hasonlóan az új szegénységhez kapcsolódó talajvesztés jelenségével jellemezték, majd a meghatározás keretei szépen lassan szúkültek, s ma már leginkább a munka világához kapcsolódik, egyfajta bizonytalan munkaerő-piaci helyzetet demonstrálva. A prekariátus a 2000-es évek elején került az akadémiai érdeklődés fókuszába, majd rövid átmeneti csendet követően 2012-ben Gay Standing írása hatására erősödött fel az érdeklődés a jelenség tudományos igényü megközelítése iránt. A prekariátusnak vagy prekaritásnak legjobb tudomásunk szerint jelenleg két megközelítési formája van: a politikai és a gazdasági (Ferge 2012).

\section{A prekariátus, mint politikai és gazdasági jelenség}

Nelsion és Rossiter az úgynevezett prekár munkavállalókról (alkalmi munkavállalók vagy rugalmas dolgozók) a következőt írták: „a politika olyan új alanyaiként próbáljuk meghatározni vagy elképzelni, amelyek bövelkednek a kollektív szervezödés és önkifejezés rájuk jellemzö, sajátos formáiban” (Lazzarato 2004 idézi Nelsion és Rossiter 2009:102) Lazzarato megfogalmazásában nem válik élesen ketté e két társadalmi (al)rendszer szerinti meghatározás. Véleménye szerint a prekaritás sokkal szélesebb és összetettebb kategória. Nem csupán a prekár munkavállalók helyzetét magába foglaló fogalom, hanem egy jóval általánosabb egzisztenciális állapotot tárgyal, amely egyszerre tekinthető úgy, mint ,a politikai elnyomás, a gazdasági kizsákmányolás és a megragadandó lehetőségek forrása" (Lazzarato 2004 idézi Nelsion és Rossiter 2009:102). Mindezek értelmében a bizonytalan munkahelyek mellett a prekaritás aspektusaiként rajzolódtak ki az életminőséget meghatározó különböző tényezők (szerzők), mint például a lakáshelyzet, a jövedelmi bizonytalanságból adódó eladósodás, a jóléti ellátások köre és igénybevételének lehetősége, a személyes emberi kapcsolatok építésére és fenntartására rendelkezésre álló idő stb.

\section{A prekariátus, mint munkaerö-piaci csoport}

Standing (2012) szerint a prekariátus elsősorban bérmunkásokból álló csoport, akik általában a bizonytalannak tekintett határozott munkaidejü szerződéssel, alacsony munkabérért dolgoznak. Tovább részletezve a jellemzőket Kelemen és Rakovics (2013) a prekariátust, mint állandósult bizonytalanságérzet mutatják be, mely a munka világában való folyamatos jelenlét hiányából adódik. Az állandó munkahely hiányának következménye pedig a munkahelyi társas kapcsolatak (melyek elsősorban formális kapcsolatok, de idővel ezek informálissá is válhatnak, ami egy erősebb kötődést és ezzel együtt erősebb védőhálót is jelenthet az érintettek számára) és a tervezhető jövőkép hiánya. A prekaritás tehát munkaeröpiaci jelenségként a biztonságtól való megfosztottságot kiszolgáltatottságot jelenti (Tordai (é. n). Szépe (2012) szerint a prekariátus, mint munkaerő-piaci csoport olyan emberi tőke tekintetében heterogén csoport, akinek munkaerő-piaci helyzete instabil (idézi Sik és Szeitl 2016). 
Azonban azt sem szabad elfelejteni, ezek a bizonyos prekár jellemzők, mint például részmunkaidő, határozott munkaidejü szerződés bizonyos társadalmi csoportok esetében inkább lehetőséget jelentenek és nem hátrányt. Gondoljunk mondjuk a diákokra, akik nyári szünetben dolgoznak, vagy azokra az egyetemi hallgatókra, akik hallgató jogviszonyuk mellett alkalmi, vagy részmunkát vállalnak azért, hogy ki tudják fizetni a tandíjukat, vagy az albérletük díját. Bár az is igaz, hogy ők munkaerő-piaci szempontból a gazdaságilag inaktívak kategóriájába tartoznak.

\section{Női prekarizmus - Férfi prekariazmus}

A munkaerő-piaci helyzet általános jellemzője, hogy a nők foglalkoztatása általában elmarad a férfiakétól. Mindemellett, az is tapasztalható, hogy a nök körében általában erösebb a prekariátus jelensége, mivel körükben magasabb a rövid távú, határozott idejü munkaszerződéssel dolgozók aránya, valamint jellemzőbb rájuk a munkaerő-piaci jelenlét folytonosságának megszakítása, például gyermekvállalás alkalmával. Ez Európában, ÉszakAmerikában és Japánban is jellemező trend (Standing 2012). A nők munkaerő-piaci jelenléte viszont elengedhetetlen a család megélhetése szempontjából. Azonban az is egyre inkább nyilvánvalóvá válik, hogy a korábban „kettős teherként” említett családanyai és foglalkoztatotti szerep egyfajta „, hármas teherré” duzzadt az elmúlt két évtizedben (Standing 2012), mikor is a gyermeknevelés és a munka világában való jelenlét kettős teherviselése mellett megjelenik egy későbbi életciklusban az idős szülőkről, családtagokról való gondoskodás is. Mindez tovább rontva ennek a csoportnak az egyébként is bizonytalan munkaerö-piaci helyzetét. Megoldást jelentene az, ha az otthoni gondozó feladatokhoz piaci bér társulna (mely hazai viszonylatban a gyermekgondozáshoz kapcsolódóan a munkaerőpiaci tapasztalattal rendelkező nők esetében meg is valósul). Addig azonban a nők az idős hozzátartozók ápolását, gondozását szabadidejükben, vagyis a „harmadik müszakban” végzik. Még aggasztóbb a helyzet annak tudatában, hogy ma már egyre általánosabbá válik a nők körében a korábban elsősorban férfiakra jellemző kenyérkereső szerep. Ennek oka nem csak abban keresendő, hogy nő az egyszülős családok száma, hanem abban is, hogy átalakultak a társadalmi szerepek.

Bár írásunk fö irányvonalát nem a női preakariátus adja, mégis érdemesnek ítéljük az iménti kitekintést, ugyanis a nők, ezen belül is a gyermeket nevelő nők munkaerő-piaci hátránya vitathatatlan. Éppen ezért a munkaerö-piaci jellemzők nemek szerinti mintázatának feltárása meghatározó momentuma lesz a lentebb olvasható elemző munkánknak. Még mielött azonban erre rátérnénk, ejtsünk néhány szót a férfiak hátrányáról. Ezt azért tartjuk fontosnak, mert a társadalomtudományi diskurzusok mintha megfelejtkeznének a férfiakról. A fentiek alapján kérdésként vetődik fel, hogy a férfiakat érinti-e és ha igen milyen módon a prekariátus jelensége. A válasz egyértelmüen igen. A megváltozott társadalmi szerepek hatására a nők munkaerő-piaci megjelenésével és foglalkoztatotti karrierjük építésének lehetőségével csökkent a házastársuk munkaerö-piaci karrierjéért önmaguk karrierjét feláldozó nők aránya. Mindezt azt jelenti, hogy egyre inkább megfigyelhetők a kettős karrierü családok, vagyis az, hogy mind a férfiak, mind a nők lehetőségeik szerint arra törekszenek, hogy szorosan kötődjenek a munkaerőpiachoz.

Visszatérve az eredeti kérdésünkhöz - igen, a férfiaknak is van veszíteni valójuk a munka világában. Gondoljuk a 2008-as pénzügyi válságra, melynek munkaerö-piaci negatív hatása számokban mérhető, s mely számos tanulmány alapját képezte. A válsággal párhuzamosan kialakuló munkaerő-piaci nehézség világszerte a férfiakat és ezen belül is a szakképzett férfiakat érintette. Nem volt ez másképpen hazai viszonylatban sem, ráadásul a korábbiakkal ellentétben nem a legalacsonyabb foglalkoztatási színvonallal rendelkező megyék, régiók férfi 
munkavállalói váltak a válság áldozatává, hanem a legkedvezőbb munkaerő-piaci lehetőségekkel rendelkező megyékben, régiókban élök.

\section{Empirikus elemzésünk jellemzői}

\section{Módszer}

Elemzésünkben arra keressük a választ, hogy a magasan kvalifikált fiatal munkavállalókra mennyire jellemző a prekariátus, mint bizonytalan munkaerő-piaci helyzet. Érintik vajon őket munkaerö-piaci nehézségek, és ha igen milyen fö meghatározó jellemzők mentén írhatók le tipikus vagy tipikusnak nem mondható mintázatok. Részben a diplomás fiatalok helyzetét vizsgálta egy, a prekariátust a centrum - periféria egyenlőtlenségi rendszerébe illesztő kutatás, melynek több eredményét figyelembe vettük saját elemzésünk tervezésekor (Szabó, 2017).

A prekariátushoz kapcsolódó első hazai empirikus vizsgálat Sik Endre és Szeitl Blanka (2016) nevéhez füződik, akik az „Integráció és dezintegráció” kutatás és az ISSP 2015. évi adatfelvétel adatbázisát használták fel munkájukhoz. Vizsgálatukban öt, illetve két változó mentén értelmezték a prekariátust.

\section{1. táblázat A prekariátus jellemzői/ismérvei. (Forrás: Sik és Szeitl 2016.)}

\begin{tabular}{|l|c|}
\hline $\begin{array}{c}\text { International Social Survey Program } \\
\text { alapján }\end{array}$ & $\begin{array}{c}\text { „Integráció és dezintegráció” kutatás } \\
\text { alapján }\end{array}$ \\
\hline - Munkaerő-piaci helyzet & $\bullet \begin{array}{l}\text { A munkaerőpiacon belüli mozgás (pl. } \\
\text { az elmúlt } 5 \text { évben) ennek megfelelően } \\
\text { megkülönböztettek stabil és instabil } \\
\text { munkaerö-piaci pozíciót, }\end{array}$ \\
- Szubjektív anyagi helyzet & $\begin{array}{l}\text { Az emberi tőke mértékével } \\
\text { - Társadalmi osztály }\end{array}$ \\
- Emberi töke & összefüggő beosztás \\
\hline
\end{tabular}

Mindezeket figyelembe véve saját kutatómunkánkban a Sik és Szeitl (2016) által meghatározott változókat, illetve attól eltérőeket határoztunk meg prekár mutatókként: gazdasági aktivitás, munkaszerződés, munkaidő jellege, családi állapot, nem, van-e gyerek a csalágban. Az iskolai végzettség azért nem került a vizsgálatunk kiemelt magyarázó változói közé, mert elemzésünk alapját eleve a diplomával rendelkező fiatalok adták.

\section{Minta és eszközök}

Kutatásunkhoz a Diplomás Pályakövető Rendszer adatbázisát használtuk fel (az adatgazda engedélyével). A DPR keretein belül 2015 tavaszán 34 felsőoktatási intézmény hallgatói fejezhették ki véleményüket különböző témacsoportok kérdéseire válaszolva. Az adatgyüjtés online kérdőívek segítségével történt, melyet több mint húszezren töltöttek ki. A lekérdezés teljes körü volt a 2010-ben, 2012-ben és 2014-ben abszolutóriumot szerzettek körében. Az általunk elemzett 2015-ös felmérés az alábbi témákat tartalmazta:

- tanulmányi életút (felsőfokú tanulmányok időszaka, felsőfokú továbbtanulás),

- külföldi tapasztalatok (nyelvismeret, külföldi tanulmányok, külföldi munkavállalás),

- átmenet a felsőoktatás és a munkaeröpiac között (a diplomaszerzés kitolódása, munkatapasztalat diplomázás előtt, első munkahely), 
- a frissdiplomás munka és munkahely, jövedelem

E témakörök közül az utolsó kettőre fókuszáltunk.

\section{Eljárás}

Elemző munkánkhoz az SPSS 22. statisztikai programcsomagot használtuk. Elemzésünkben egyváltozós és többváltozós elemzési technikákat alkalmaztunk. Előbbi segítségével átfogó képet kaptunk az adatbázisról, utóbbiak alkalmazása lehetővé tette két vagy több változó közötti összefüggések feltárását. Az elemzés során a leggyakrabban használt többváltozós elemzési formák közé tartozott a kereszttábla-elemzés valamint a $\chi^{2}$ statisztika.

\section{Eredmények}

Mielőtt bemutatjuk elemzésünk főbb eredményeit, elötte röviden szólunk a vizsgált minta néhány általános jellemzőjéről. Elsősorban azokra a paraméterekre koncentrálunk, melyeket később a prekár mutatókkal összefüggésben vizsgálni fogunk.

A megkérdezett fiatalok 61\%-a nő, 39\%-a pedig férfi. Családi állapot szerint a következő jellemzőkkel bírnak: 41\% egyedülálló, 26,7 \%-uk házas, 29,4\% élettársi kapcsolatban él, $2,6 \%$ elvált és $0,4 \%$ válaszolta azt, hogy özvegy. A nök körében magasabb a házasok, az elváltak és a tartós kapcsolatban élők aránya a férfiakhoz viszonyítva, míg az egyedül állók létszáma a férfiaknál magasabb.

Egyötödük nevel 18 év alatti gyermeket. Ezen belül a többség egy gyermekröl $(58,2 \%)$ gondoskodik. 32,4\%-uk két, 8,3\%-uk három, háromnál több gyermeke pedig 1\%-uknak van.

A megkérdezettek 36\%-a az abszolutórium megszerzését követően egy hónapon belül talált munkát, $10,5 \%$ pedig arról számolt be, hogy a megkérdezés időpontjában is munkát keres.

A válaszadók 6,3 \%-a dogozott már külföldön és közel ennyien válaszolták azt, hogy jelenleg is külföldi munkahelyük van. Többségük (70\%) külföldi munkája részben vagy egészben kapcsolódott a megszerzett diplomához. 28\%-uk tervezi, hogy elkövetkezendő 5 éven belül külföldön fog majd dolgozni.

A mintába került fiatalok munkaerő-piaci státusz szerinti mintázatáról a következő kép rajzolódott ki: többségük, 85\%-uk a gazdaságilag aktívak csoportjába sorolta magát, ezen belül is négyötödük alkalmazottként dolgozik. Jelenleg is nappali tagozatos hallgató $6,2 \%$, míg 3,7\% munka nélkül van. Gyermekgondozási szabadság miatt 3,7\%-uk van távol a munka világától, a háztartásbeli, valamint az egyéb inaktív eltartott státuszban lévők aránya egy százalék alatti. Közel egyharmaduk megtapasztalta már a munkanélküliséget a végzést követően.

A frissdiplomások munkaerő-piaci részvételi kedvező képet fest, 88\%-uk dolgozott a megkérdezés időpontjában. 8,4\% válaszolta azt, hogy bár most nem dolgozik, de volt már munkahelye, s 3,4\% pedig még sohasem dolgozott. Azok, akik a megkérdezési időpontjában dolgoztak többségében $(82,7 \%)$ állandó, határozatlan időtartamra szóló szerződésser rendelkeztek. 14,7 \%-uk határozott munkaszerződéssel lett foglalkoztatva, míg 2,7\% alkalmi jellegü, megbízási szerződéssel dolgozott.

A gazdasági aktivitást a képzési szinttel összefüggésben vizsgálva szignifikáns eredményeket kaptunk $(p=0,000)$. A 2. számú táblázat eredményei azt mutatják, hogy minden képzési típusban az alkalmazottak vannak a legtöbben. Ehhez képest alacsony és közel azonos az önfoglalkoztatók és vállalkozók aránya. Ami szembetűnő, hogy az alapszakkal (Ba/BSc) rendelkezők körében a legmagasabb a munkanélküliek aránya. A második legmagasabb adat a mesterszakot végzettekhez kötődik. A legjobb helyzetben az egységes és osztatlan képzésbe valamint a hagyományos egyetemi, föiskolai képzésben végzettek vannak. A végzettek egy része nappalis hallgatóként jelenik meg újra a felsőoktatás rendszerében. Kiemelten igaz ez az 
alapszakon diplomát szerzettek esetében, akik részéről ez agy logikus döntésként értelmezhetö, a fentebb leírtak ismeretében (2. táblázat).

2. táblázat. Mi az Ön jelenlegi fö munkaerö-piaci státusza? (\%) N=19645. (Forrás: R. Fedor és Fónai)

\begin{tabular}{|c|c|c|c|c|c|c|c|c|}
\hline 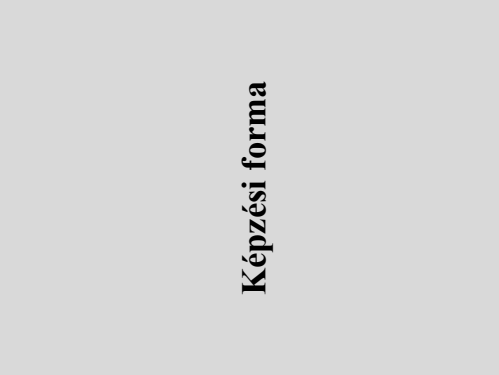 & 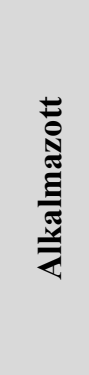 & 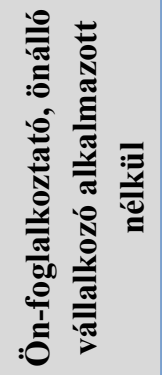 & 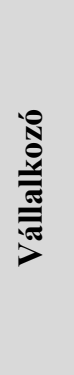 & 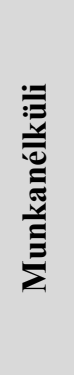 & 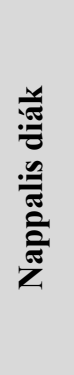 & 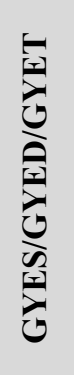 & 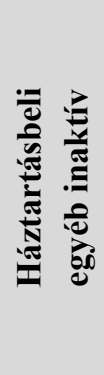 & : \\
\hline $\mathbf{B a} / \mathbf{B S c}$ & 78,0 & 2,4 & 2,2 & 4,4 & 8,8 & 3,2 & 1,1 & 100,0 \\
\hline Ma/MSc & 84,6 & 2,4 & 2,4 & 3,6 & 3,9 & 2,7 & 0,4 & 100,0 \\
\hline $\begin{array}{l}\text { Egységes és osztatlan képzés (pl. } \\
\text { jogász, orvosképzés) }\end{array}$ & 85,5 & 2,3 & 1,6 & 1,7 & 3,1 & 5,1 & 0,8 & 100,0 \\
\hline Egyetemi - hagyományos képzés & 81,6 & 4,0 & 2,8 & 2,0 & 2,8 & 6,1 & 0,7 & 100,0 \\
\hline Főiskolai - hagyományos képzés & 84,4 & 2,2 & 2,1 & 2,9 & 1,6 & 5,7 & 1,2 & 100,0 \\
\hline
\end{tabular}

$\left(\chi^{2} \mathrm{p}=0,000\right)$

Arra is kíváncsiak voltunk, hogy a munkaerö-piaci részvétel hogyan alakul, külön vizsgálva a férfiakat és nőket. Alapvető különbséget találtunk a levelezőn és nappalin végzett hallgatók válaszaiban. Nem meglepő, hogy a levelezősök között vannak a legtöbben azok, akik úgy nyilatkoztak, hogy jelenleg is dolgoznak, hiszen ök általában éppen azért választják a levelező tagozatot, hogy a tanulmányikat össze tudják egyeztetni a munkahelyi feladataikkal. Ami viszont figyelemre méltó, az az, hogy mind a nappalin, mind a levelezőn végzettek csoportján belül a nők a férfiakhoz képest nagyobb arányban számoltak be megszakított munkaerö-piaci jelenlétről, vagyis arról, hogy ,,most nem dolgozik, de volt már munkahelye”. Bár a válaszokból az nem derül ki, hogy a megszakított munkaerő-piaci karriernek mi az oka, mégis kijelenthetjük, hogy a folytonos munkaerö-piaci jelenlét hiánya - amely egyértelmúen egyfajta bizonytalanságként értelmezhető - inkább jellemző a nőkre, mint a férfiakra. (3. táblázat)

3. táblázat. Munkaerő-piaci részvétel szerinti megoszlás (\%) $N=20$ 996. (Forrás: R. Fedor és Fónai)

\begin{tabular}{|c|r|r|r|r|}
\hline & Nő (nappali) & Férfi (nappali) & Nö (levelező) & Férfi (levelező) \\
\hline Jelenleg (is) dolgozik & 76,8 & 82,1 & 88,8 & 95,5 \\
\hline Sosem dolgozott & 9,3 & 8,4 & 0,6 & 0,7 \\
\hline $\begin{array}{c}\text { Most nem dolgozik, de már } \\
\text { volt munkahelye }\end{array}$ & 13,9 & 9,5 & 10,6 & 3,8 \\
\hline Összesen & 100,0 & 100,0 & 100,0 & 100,0 \\
\hline
\end{tabular}

$\left(\chi^{2} \mathrm{p}=0,000\right)$ 
Ugyanez mondható el egy következő prekár mutatóról, az alkalmi, megbízási vagy határozott idejü munkaszerződésröl. A nappalis férfiak 19,9\%, míg a nappalis nők 28,2\%-a rendelkezik e csekélyebb munkabiztonságot jelentő szerződéstípussal. (lásd. 4. táblázat)

4. táblázat A munkaszerzödés jellege és a képzési forma (\%) N=17 056. (Forrás: R. Fedor és Fónai)

\begin{tabular}{|c|r|r|r|r|}
\hline & Nő (nappali & Férfi (nappali) & Nő (levelezö) & Férfi (levelezö) \\
\hline Határozatlan, állandó & 71,8 & 80,1 & 88,5 & 91,0 \\
\hline Határozott & 24,0 & 16,2 & 10,1 & 7,7 \\
\hline $\begin{array}{c}\text { Alkalmi vagy megbízási } \\
\text { jellegü }\end{array}$ & 4,2 & 3,7 & 1,4 & 1,3 \\
\hline Összesen & & & & 100,0 \\
\hline
\end{tabular}

$\left(\chi^{2} \mathrm{p}=0,000\right)$

A gyermek/gyermekek jelenléte várakozásainkkal ellentétes összefüggést mutat a munkaszerződések jellegével. Azt feltételeztük, hogy a gyerekesek körében magasabb lesz az alkalmi, megbízási vagy határozott idejü munkaszerződéssel bírok aránya, mint a gyermekteleneknél. Ennél a feltevésünknél abból indultunk ki, hogy a gyermek jelenlétéből adódó nagyobb felelösség, anyagi teher afelé irányítja a munkavállalókat, hogy akár kedvezőtlenebb munkafeltételek mellett is elvállaljanak egy adandó munkalehetőséget. Eredményeink azonban azt mutatják, hogy a gyermekesek 10,6\%-a, míg a gyermektelenek 21,4\%-ra jellemzőek az ilyen típusú szerződések. Ez két tényező „számlájára írható”.

Az egyik az életkori hatás, a másik pedig a gyermek jelenlétével összefüggő kockázatmentes munkavállalási attitüd. Az életkori hatásról a következőket gondoljuk: a gyermektelenek vélhetően a fiatalabbak, akik munkaerő-piaci pályafutásuk elején pályakezdőként többször találkoznak és fogadnak el az alkalmi, megbízási vagy határozott idejü lehetőségeket. A gyermekkel összefüggő biztonsági attitüd pedig azt jelentheti, hogy a gyermekesek nem mennek bele instabil helyzetekbe. Inkább választják a hosszabb időre szóló $\mathrm{s}$ talán kevesebb kreativitást, nagy kiugrást jelentő, de ugyanakkor kockázatmentes lehetőséget, mint a gyermektelenek. (5. táblázat)

5. táblázat Munkaszerzödés jellege és gyermek (\%) N=16 866. (Forrás: R. Fedor és Fónai)

\begin{tabular}{|c|r|r|}
\hline & Van gyermeke & Nincs gyermeke \\
\hline Határozatlan, állandó & 89,4 & 78,6 \\
\hline Határozott & 8,8 & 18,0 \\
\hline $\begin{array}{c}\text { Alkalmi vagy megbízási } \\
\text { jellegü }\end{array}$ & 1,8 & 3,4 \\
\hline Összesen & 100,0 & 100,0 \\
\hline
\end{tabular}

$\left(\chi^{2} \mathrm{p}=0,000\right)$

A munka világában való folyamatos jelenlét a gyermektelenek előnyét mutatja $(9,2 \%)$. A gyermeket nevelök körében közel kétszer ennyien válaszolták azt, hogy volt már munkahelyük, de jelenleg nem dolgoznak (6. táblázat). 
6. táblázat Munkaerö-piaci részvétel és gyermek (\%) N=19 316. (Forrás: R. Fedor és Fónai)

\begin{tabular}{|c|r|r|}
\hline & Van gyermeke & Nincs gyermeke \\
\hline Jelenleg (is) dolgozik & 82,1 & 83,5 \\
\hline Sosem dolgozott & 1,1 & 7,3 \\
\hline $\begin{array}{c}\text { Most nem dolgozik, de már } \\
\text { volt munkahelye }\end{array}$ & 16,8 & 9,2 \\
\hline Összesen & 100,0 & 100,0 \\
\hline$\left(\chi^{2} \mathrm{p}=0,000\right)$ & &
\end{tabular}

A munkaerő-piaci hierarchiában elfoglalt kedvező helynek sokféle elönye van. Magasabb jövedelmet, több szabadidőt, saját időbeosztást kínálhat az érintettek számára. Mindemellett az is fontos, hogy az emberi tőkéjébe beruházó egyén befektetései megtérülnek-e a munkaerőpiacon? Ebben az értelemben azt vizsgáltuk, hogy a frissdiplomások végzettségüknek megfelelöen diplomás munkakörben dolgoznak-e vagy sem? Az alábbi táblázatok (7. és 8.) egyértelmü női hátrányról árulkodnak. Mind a felsö-, közép- és alsó vezetők körében alulreprezentáltak a nők.

Összesítve a három vezetői szinten arányukat, azt tapasztaljuk, hogy 17\%-uk tölt be valamilyen vezetői pozíciót, míg a férfiaknál ugyan ez az arány $26,7 \%$. Még kedvezötlenebb kép tárul elénk a gyermeket nevelő nőket és férfiakat összehasonlítva. A férfiak dominanciája 43,3\%-ban mérhetö a nök 23,4\%-kához képes. A $20 \%$-os különbség jelentős, melyet megerősít korábbi megyei vizsgálatunk eredménye, mely szerint az esetek 95\%-ban a nők maradnak otthon a gyermekükkel gyermekgondozási szabadságon (R. Fedor, 2105). A megszakított munkaerő-piaci karrier jellemzője pedig, hogy az otthon töltött időszakban a nők munkaerö-piaci karrierje nem csak stagnál, de akár egy lefelé történő mobilitás is megfigyelhető (Róbert és Bukodi, 2002). Az is figyelemre méltó, hogy a „beosztott nem diplomás" státuszra vonatkozó adatok szintén a nők hátrányát erősíti.

7. táblázat Vezetö pozícióban dolgozók aránya nemek és gyermek szerint (\%) $N=14858$. (Forrás: R. Fedor és Fónai)

\begin{tabular}{|c|r|r|r|r|}
\hline Beosztás & \multicolumn{1}{|c|}{ Nő } & \multicolumn{1}{c|}{ Férfi } & Nő gyermekkel & \multicolumn{1}{c|}{ Férfi gyermekkel } \\
\hline Felsővezető & 2,2 & 3,2 & 4,0 & 6,7 \\
\hline Középvezető & 8,6 & 13,1 & 13,9 & 23,6 \\
\hline Alsó vezető & 6,2 & 10,4 & 5,5 & 13,0 \\
\hline Beosztott diplomás foglalkozás & 67,8 & 62,7 & 61,8 & 46,5 \\
\hline Beosztott nem diplomás foglalkozás & 15,2 & 10,6 & 14,7 & 10,2 \\
\hline Összesen & 100,0 & 100,0 & 100,0 & 100,0 \\
\hline
\end{tabular}

$\left(\chi^{2} \mathrm{p}=0,000\right)$

A gyerekkel rendelkező felsővezetők és középvezetők 60\%-a férfi, a középvezetőknél ez az arány még magasabb, 66\%. A nagyságrendbeli különbségek a beosztás további szintjein megfordulnak, a beosztott diplomás és nem diplomás foglalkozást betöltők a nők ,javára” fordul át. Ezekben a kategóriákban a nők arány a meghatározó (61 és 63\%) (8. táblázat). 
8. táblázat. Vezetö pozícióban dolgozók aránya nemek és gyermek szerint (\%) $N=14548$ (Forrás: R. Fedor és Fónai)

\begin{tabular}{|c|c|c|c|c|c|}
\hline & $\begin{array}{c}\text { Felsö } \\
\text { vezető }\end{array}$ & $\begin{array}{c}\text { Közép- } \\
\text { vezető }\end{array}$ & $\begin{array}{c}\text { Alsó } \\
\text { vezető }\end{array}$ & $\begin{array}{c}\text { Beosztott diplomás } \\
\text { foglalkozás }\end{array}$ & $\begin{array}{c}\text { Beosztott nem } \\
\text { diplomás foglalkozás }\end{array}$ \\
\hline Nő gyermekkel & 41,7 & 41,2 & 33,6 & 61,2 & 63,1 \\
\hline Férfi gyermekkel & 58,3 & 58,8 & 66,4 & 38,8 & 36,9 \\
\hline Összesen & 100,0 & 100,0 & 100,0 & 100,0 & 100,0 \\
\hline
\end{tabular}

$\left(\chi^{2} \mathrm{p}=0,000\right)$

Végezetül arra is kíváncsiak voltuk, hogy mennyire elégedettek a frissdiplomások a munkájuk bizonyos paramétereivel. Ezen túl az is felmerült kérdésként, hogy van-e különbség a férfiak és nők véleményében.

Megállapíthatjuk, hogy a munka összességével, tartalmi részével, tárgyi és személyi körülményeivel nagyjából hasonló mértékü elégedettségüket fejezték ki a válaszadók. Ettől valamivel alacsonyabb elégedettség jellemzi a szakmai előmenetel lehetőségét, a presztízst és a jövedelmet. Utóbbi került a rangsor végére. A férfiak és nők munkával kapcsolatos elégedettsége között meghatározó különbséget nem tapasztaltunk (9.ábra).

9. ábra. Mennyire elégedett a munka....(Forrás: R. Fedor és Fónai)

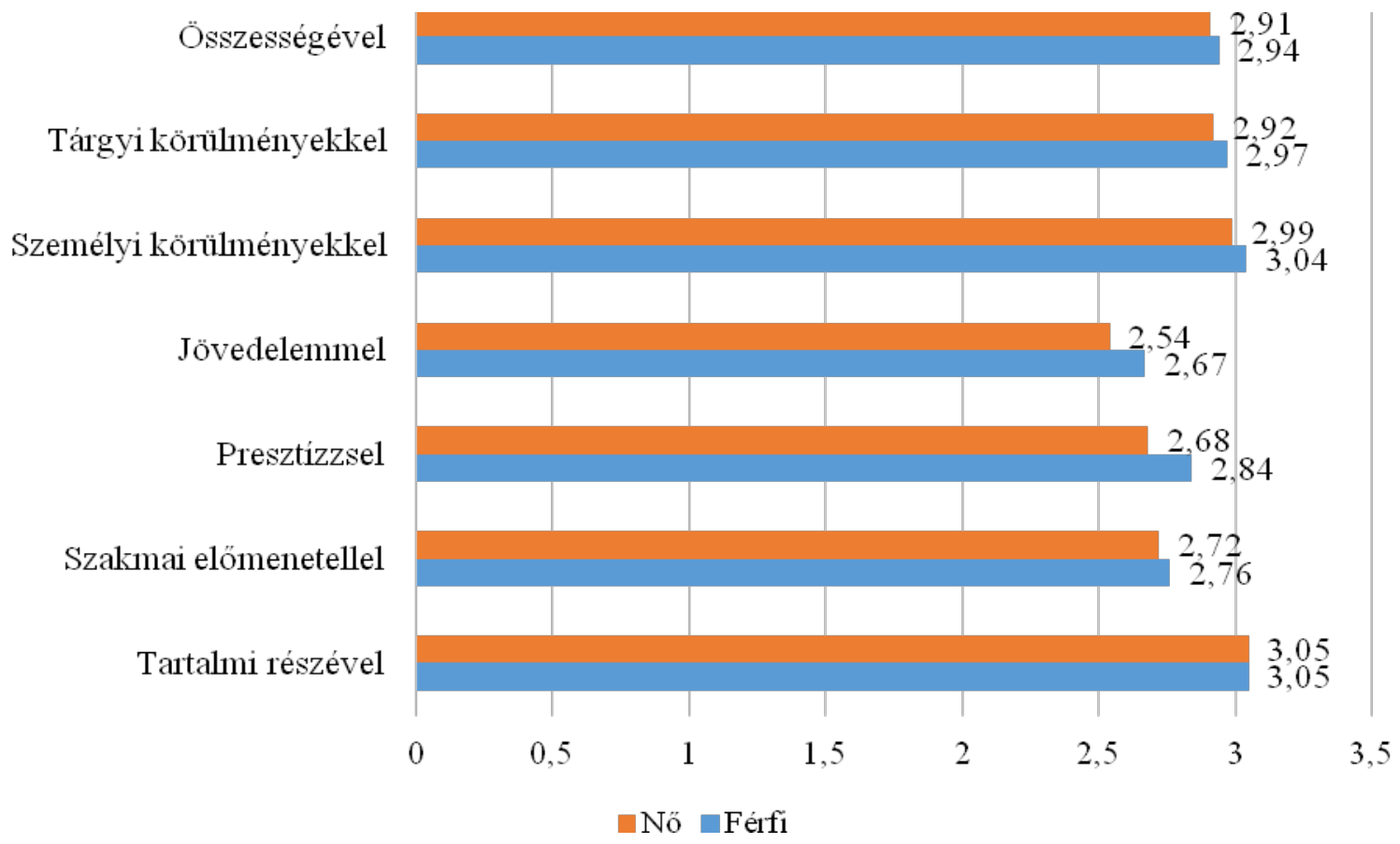

\section{Konklúzió}

Eredményeink alapján megállapíthatjuk, hogy a diplomával rendelkező fiatalok általános munkaerö-piaci helyzete kedvező. Azonban az is elmondható, hogy ezen belül is a magasabb végzettségi szint véd a munkanélküliséggel szemben. Hasonló megállapításra jutottunk az ún hagyományos (osztatlan, egyetemi, főiskolai) diplomával rendelkezők vonatkozásában is. 
A munkaerő-piaci részvétel statisztikailag releváns összefüggést mutatott a férfiak és a nők vonatkozásában. A nőkre jellemzőbb a munkaerő-piaci jelenlét megszakítása, mint a férfiakra. A munkaszerződések jellege és a gyermek jelenléte közötti összefüggés nem bizonyította előzetes feltevésünket. A gyermekesekre kevésbé jellemző az alkalmi, megbízási vagy határozott idejü szerződéssel való munkavégzés. A munkaerő-piaci hierarchiában elfoglalt hely vonatkozásában egyértelmü női hátrány rajzolódott ki. Ez összefüggésben van a munkaerő-piaci karrier megszakításával, mely szintén a nőkre jellemző inkább.

Összességében kijelenthetjük, hogy a prekariátus jelensége a vizsgált diplomások között is érvényesül. A prekár jelenségek jelentős nemek és végzettségi szint szerinti különbségeket mutatnak, ez igazolja a szakirodalmi állításokat is. A prekariátussal összefüggő hazai írások, elemző munkák köre igen szük. Eddig legjobb tudomásunk szerit Sík és Szeitl (2016) publikált e témában. Jelen írásunkkal a prekaritás jelenségének egy más típusú elemzésére vállalkoztunk a magasan kvalifikált fiatalok csoportja körében. További kutatási terveink között szerepel a prekariátus vizsgálatának mélyebb, átfogóbb, további szempontokat is figyelembe vevő, egyéb társadalmi csoportokra is kiterjedő, további összefüggéseket feltáró elemzésnek a lebonyolítása.

\section{IRODALOM}

Ferge, Zs. (2012): Prekariátus Magyarországon. Fordulat 19. 117-125. http://fordulat.net/pdf/19/F19 Ferge-interju.pdf

Kelemen, Zs., Rakovics, M. (2013): Prekaritás és habitus. Kérdések a prekariátusról, mint új osztályról és kategóriáról, Pierre Bourdieu társadalomelméletének tükrében. In: Hajdu et al. (szerk.): Kötetlen. Az ELTE Angelusz Róbert Társadalomtudományi Szakkollégium tanulmánykötete. ELTE ARTSZ, Budapest.13-22.

LaVaque-Manty, M. (2012): Hogyan bukkanhatunk elméleti fogalmakra a való világban? A prekariátus esete. Fordulat 19. 53.74.

Lazzarato, M. (2004): The Political Form of Coordination. http://eipcp.net/transversal/0707/lazzarato/en

Neilson, B., Rossiter, N. (2009): A prekaritás mint politkai fogalom. http://epa.oszk.hu/02100/02121/00017/pdf/EPA02121_fordulat_19_100-114.pdf. Letöltés 2017.07.28.

R. Fedor, A. (2015): Egyensúlyban? A munkaerö-piaci karriertől a familiarizmusig. Debrecen: Debreceni Egyetemi Kiadó, 2015. 252 p.

Róbert, P., Bukodi, E. (2002): Dual career pathways: The occupational attainment of married couples in Hungary. European Sociological Review 18/2, 217-232.

Szabó, F. (2017): Munkaerő-piaci helyzetkép Derecske járás területén élő fiatalok körében. A prekariátus új jelenségeinek vizsgálata. PhD disszertáció. Debreceni Egyetem, Kerpely Kálmán Doktori Iskola

Sik, E., Szeitl, B. (2016): A prekariátus mint munkaerö-piaci csoport. METSZETEK, 6 3-40.

Standing, G. (2012): The Precariat: The New Dangerous Class. Bloomsbury Academic.

Szépe, A. (2012): Prekariátus. Fordulat 19. 11-20.

Tordai B. (é. n.): A prekariátus fogalmáról. https://www.academia.edu/8358321/ 